\title{
Selective Separation of Hematite by a Synthesized Depressant in Various Scales of Anionic Reverse Flotation
}

\author{
Arash Tohry ${ }^{1}$, Reza Dehghan ${ }^{1}$, Saeed Chehreh Chelgani ${ }^{2, *}{ }^{\mathbb{C}}$, Jan Rosenkranz ${ }^{2}$ and \\ Omid Ali Rahmani ${ }^{3}$ \\ 1 Mining and Metallurgical Engineering Department, Yazd University, 89195-741 Yazd, Iran; \\ arashtohry@stu.yazd.ac.ir (A.T.); rdehghans@yazd.ac.ir (R.D.) \\ 2 Minerals and Metallurgical Engineering, Department of Civil, Environmental and Natural Resources \\ Engineering, Luleå University of Technology, SE-971 87 Luleå, Sweden; jan.rosenkranz@ltu.se \\ 3 Chadormalu Mining and Industrial Company, 89591-55712 Yazd, Iran; rahmani@chadormalu.com \\ * Correspondence: saeed.chelgani@ltu.se; Tel.: +46(0)737730927
}

Received: 24 January 2019; Accepted: 18 February 2019; Published: 20 February 2019

\begin{abstract}
Demand for high-quality iron concentrate is significantly increasing around the world. Thus, the development of the techniques for a selective separation and rejection of typical associated minerals in the iron oxide ores, such as phosphorous minerals (mainly apatite group), is a high priority. Reverse anionic flotation by using sodium silicate (SS) as an iron oxide depressant is one of the techniques for iron ore processing. This investigation is going to present a synthesized reagent "sodium co-silicate (SCS)" for hematite depression through a reverse anionic flotation. The main hypothesis is the selective depression of hematite and, simultaneously, modification of the pulp $\mathrm{pH}$ by SCS. Various flotation experiments, including micro-flotation, and batch flotation of laboratory and industrial scales, were conducted in order to compare the depression selectivity of SS versus SCS. Outcomes of flotation tests at the different flotation scales demonstrated that hematite depression by SCS is around 3.3\% higher than by SS. Based on flotation experiment outcomes, it was concluded that $\mathrm{SCS}$ can modify the $\mathrm{pH}$ of the process at $\sim 9.5$, and the plant reagents (including $\mathrm{NaOH}, \mathrm{Na}_{2} \mathrm{CO}_{3}$, and SS gel) can be replaced by just SCS, which can also lead to a higher efficiency in the plant.
\end{abstract}

Keywords: anionic reverse flotation; phosphorus; depression; sodium co-silicate

\section{Introduction}

Due to the high demand for iron and steel from various industries, even iron ores which have exhibited a complicated mineralogy can be considered as potential resources and can be processed by different beneficiation methods [1-3]. Magnetic separation and reverse flotation are the most efficient techniques that have been widely used for the separation and removal of gangue phases in the iron oxide ores [1,2,4]. Reverse flotation of iron oxide ores can be performed by anionic and cationic collectors, while iron oxides are depressed by various chemicals (starch, water glass, sodium humate, dextrin, sodium carboxymethyl, etc.) [5-8]. It was understood that depressants are typically coating the surface of minerals by inducing a hydrophilic film and prevent bubble-particle attachment [7]. However, due to various interactions with the flotation slurry, depressants can simultaneously act as $\mathrm{pH}$ modifiers or flocculants. It was reported that starch in the industrial reverse hematite flotation separation from quartz can be used as a depressant and flocculant $[5,6]$.

Among the gangue minerals found in iron oxide ores, phosphorous minerals (mainly in the form of apatite group) are the most unwanted associated minerals for the steelmaking process. Phosphor decreases the ductilibility of steels by increasing its brittleness [9]. Where there are many 
high-phosphorus iron mines around the world (Iran, Sweden, and Mexico) [3,10,11], reverse anionic flotation, floating phosphorous minerals and depressing iron oxides using sodium silicate (SS), is the main traditional method for separation of iron minerals and removing phosphorus content. However, it was reported that, in some cases, SS is not an efficient depressant for iron oxides when phosphorous minerals are among the associated gangue minerals [3]. Thus, further investigations on synthesizing depressants for a selective reverse flotation of iron oxide ores are essential.

The main aim of this study is introducing a newly synthesized depressant "sodium co-silicate (SCS)" for a reverse anionic flotation separation of hematite from fluorapatite at different scales (micro, batch, and industrial). Micro-flotation experiments are conducted by using pure minerals in order to compare the performance of SCS and SS. Batch and industrial scale experiments are performed by using samples from the Iranian Chadormalu iron ore processing plant and considering the plant operating conditions. For comparison purposes, experiments are carried out by using both SS and SCS with the same conditions. The outcomes of this investigation can lead to higher efficiency and lower reagent consumptions in the plant by using SCS.

\section{Materials and Methods}

\subsection{Materials}

The XRD analysis of the feed from Chadormalu iron ore processing plant showed that the main minerals in the feed are hematite, magnetite and fluorapatite (small amount of quartz and ankerite). To simulate the feed, pure fluorapatite and hematite were prepared and used in micro-flotation tests. Energy dispersive X-ray spectroscopy (EDS) (Model Vegato, RONTEC's EDX Model, Tescan, Brno, Czech Republic) and potassium dichromate titration were used to analyze these two pure minerals (Table 1). The pure minerals were freshly crushed and pulverized by a hammer and ground in a porcelain mortar. The $-75+25 \mu \mathrm{m}$ fraction was used for micro-flotation tests. For bench-scale flotation tests, samples were collected from the feed stream to the flotation circuit in the plant. The grades of Fe and $\mathrm{P}$ in the batch flotation feed samples were $59.11 \%$ and $0.79 \%$, respectively. The d 80 of the feed sample was $-45 \mu \mathrm{m}$. In the plant, Alke $742 \mathrm{FL}$ (type of carboxylic acids which contains an ester agent group) is used as a collector (produced at the Isfahan Copolymer Chemical Co. Isfahan, Iran), together with a mixture of $\mathrm{NaOH}: \mathrm{Na}_{2} \mathrm{CO}_{3}$ as a $\mathrm{pH}$ modifier and sodium silicate (SS) as the hematite depressant. Collector consumption in the plant is around $350 \mathrm{~g} / \mathrm{t}$.

Table 1. Distribution of main elements in the used mineral samples.

\begin{tabular}{cccccc}
\hline \multirow{2}{*}{ Minerals } & \multirow{2}{*}{ Analysis Method } & \multicolumn{4}{c}{ Distribution of Main Elements (\%) } \\
\cline { 3 - 5 } & & Ca & P & F & Fe \\
\hline Fluorapatite & EDS & 37.71 & 18.17 & 1.11 & - \\
Hematite & Wet chemistry (titration) & - & - & - & 69.11 \\
\hline
\end{tabular}

The sodium co-silicate "SCS" $\left(\mathrm{Na}_{4} \mathrm{SiCO}_{6}\right)$ is a modified depressant and, unlike the SS gel, is a solid white powder. SCS is obtained from the synthesis of sodium metasilicate with sodium carbonate and caustic soda. Based on the synthesizing conditions, SCS may have different properties (Table 2). SCS can modify the pH of a slurry solution and set it in the range of 9 to 10 . In this study, SCS with the "PS-SCS 23" code was used. For comparison purposes, all micro, batch, and industrial flotation tests were performed with the plant conditioning in the presence of different depressants (SS vs. SCS). 
Table 2. Technical specification of various SCS types. (CBC: representative of CaO content (mg) in $1 \mathrm{~g}$ SCS).

\begin{tabular}{|c|c|c|c|c|}
\hline \multirow{2}{*}{ Product Name } & \multicolumn{4}{|c|}{ Specification } \\
\hline & $\mathrm{SiO}_{2} \%$ & $\mathrm{CBC}(\mathrm{mg} \mathrm{CaO} / \mathrm{g})$ & Bulk Density $\left(\mathrm{g} / \mathrm{cm}^{3}\right)$ & LOI $\left(450{ }^{\circ} \mathrm{C}\right.$ for $\left.30 \mathrm{~min}\right)$ \\
\hline PS-SCS 23 & 25 & $\min 130$ & $350-550$ & $10-15$ \\
\hline PS-SCS 23-2 & 20 & $\min 130$ & $350-550$ & $10-15$ \\
\hline PS-SCS 20 & 21 & $\min 130$ & $350-450$ & $10-13$ \\
\hline
\end{tabular}

\subsection{Micro and Batch Flotation Experiments}

Micro-flotation tests were performed in a $150 \mathrm{~mL}$ modified Hallimond tube flotation cell, and by using $1.5 \mathrm{~g}$ each of pure minerals at a $\mathrm{pH}$ of 9.5. The samples were conditioned for 3 min under constant agitation then depressant was added and agitated for $3 \mathrm{~min}$. The $\mathrm{pH}$ was adjusted and then the collector solution $(1 \mathrm{wt} \%)$ was added and conditioned for another $3 \mathrm{~min}$. After that, flotation tests were carried out for $3 \mathrm{~min}$ and the floated particles were collected and dried. The main aim of conducting micro-flotation experiments was to explore the potential of using SCS instead of SS.

For the batch flotation tests, samples from the plant feed (dephosphorization unit) are subjected to a Denver flotation machine (D12, Metso, Helsinki, Finland) with a 2 L cell capacity. In this stage, the main aim for conducting experiments was optimizing the SCS dosage. The solid percentage in the batch process was set to $30 \%$ and the agitation rate was $1200 \mathrm{rpm}$. The airflow rate was $3.8 \mathrm{~L} / \mathrm{min}$. First, conditioning time for the slurry was 4 min without adding reagent. Then, the pulp with $\mathrm{pH} \sim 9.5$ was conditioned by SCS as a depressant for $3 \mathrm{~min}$. In the next step, similar to the conditioning in the plant, the collector was added and conditioned for three more minutes.

\subsection{Industrial Flotation Experiments}

In the flotation circuit of the Chadormalu plant, SS is used as the iron oxides depressant. The dephosphorization flotation circuit consists of rougher, cleaner, and scavenger circuits (each having three stages) (Figure 1). Flotation feed is the concentrate which has been produced from a high-gradient magnetic separator (HGMS). The rougher and cleaner stages consist of 10 cells with $11 \mathrm{~m}^{3}$ capacity. The scavenger stage consists of 10 cells with $3.3 \mathrm{~m}^{3}$ capacity. To compare SS vs. SCS at the industrial scale, three parallel lines (out of five lines) were used based on different conditions (Table 3). During the tests, a homogeneous stockpile was prepared and fed to the plant. The feed rate for the experiments was close to the common plant feed rate. The flotation tests were run on two consecutive days. In the first 24 hours the SS, and in the second $24 \mathrm{~h}$ the SCS depressant were examined (Table 3).

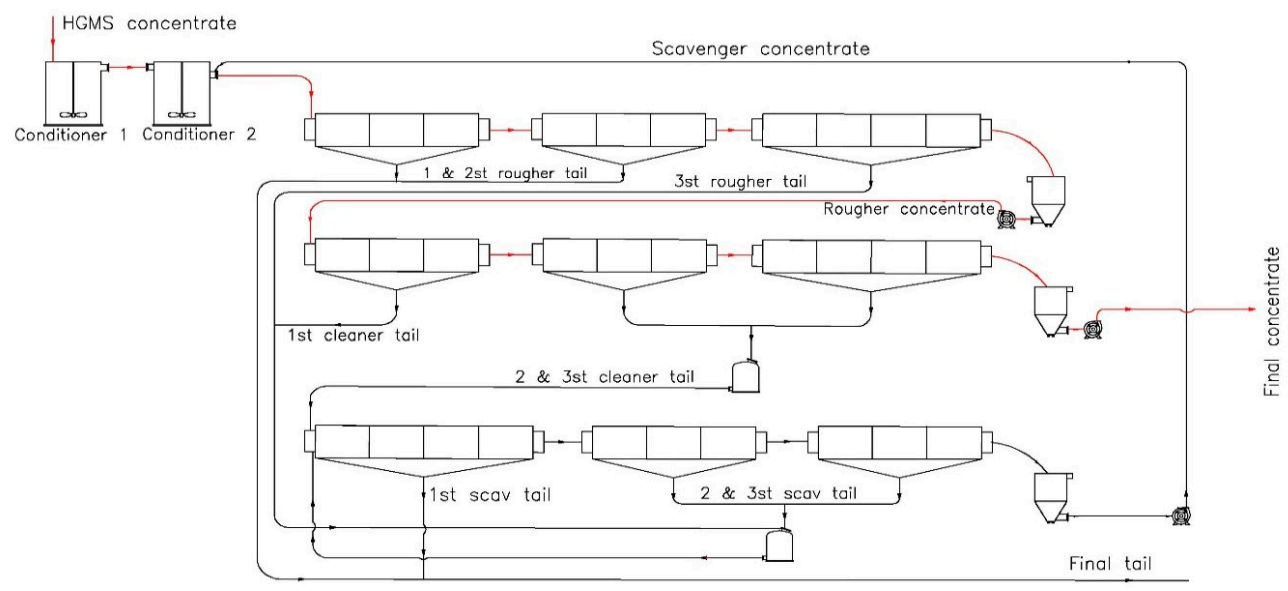

Figure 1. Simplified process flowsheet of the dephosphorization reverse flotation circuit in the Chadormalu processing plant. 
Table 3. Characterization of flotation feed of the plant during the industrial experiments.

\begin{tabular}{ccccccc}
\hline \multirow{2}{*}{ Production Line Number } & \multicolumn{5}{c}{ Plant Flotation Feed Characterization } \\
\cline { 2 - 7 } & \multicolumn{3}{c}{ The First 24 h } & \multicolumn{3}{c}{ The Second 24 h } \\
\cline { 2 - 7 } & Solid (ton) & Fe\% & $\mathbf{P \%}$ & Solid (ton) & $\mathbf{F e} \%$ & $\mathbf{P \%}$ \\
\hline Production line\#1 & 93.00 & 60.87 & 0.711 & 93.00 & 59.91 & 0.699 \\
Production line\#2 & 87.00 & 59.45 & 0.678 & 89.00 & 59.85 & 0.695 \\
Production line\#3 & 94.00 & 60.21 & 0.681 & 91.00 & 60.35 & 0.691 \\
Average & 91.33 & 60.18 & 0.690 & 91.00 & 60.04 & 0.695 \\
\hline
\end{tabular}

\section{Results and Discussions.}

\subsection{Micro-Flotation Experiments}

Micro-flotation outcomes (Figure 2) indicate that hematite recovery in the absence of depressants is about $74 \%$, while by adding depressants it increases significantly (the iron recovery increases by more than $20 \%$ ). Adding depressants slightly decreases the flourapatite recovery in the froth phase. This slight drop in fluorapatite floatability is probably due to the interactions between the collector and the depressants [12]. The depression of hematite by SCS is 3.5\% higher than SS (Figure 2). Moreover, in the presence of SCS, the fluorapatite recovery in froth phase is higher than SS. These results demonstrate that (i) the presence of depressant generally has no significant effect on the fluorapatite floatability, and (ii) the SCS is more efficient than SS.

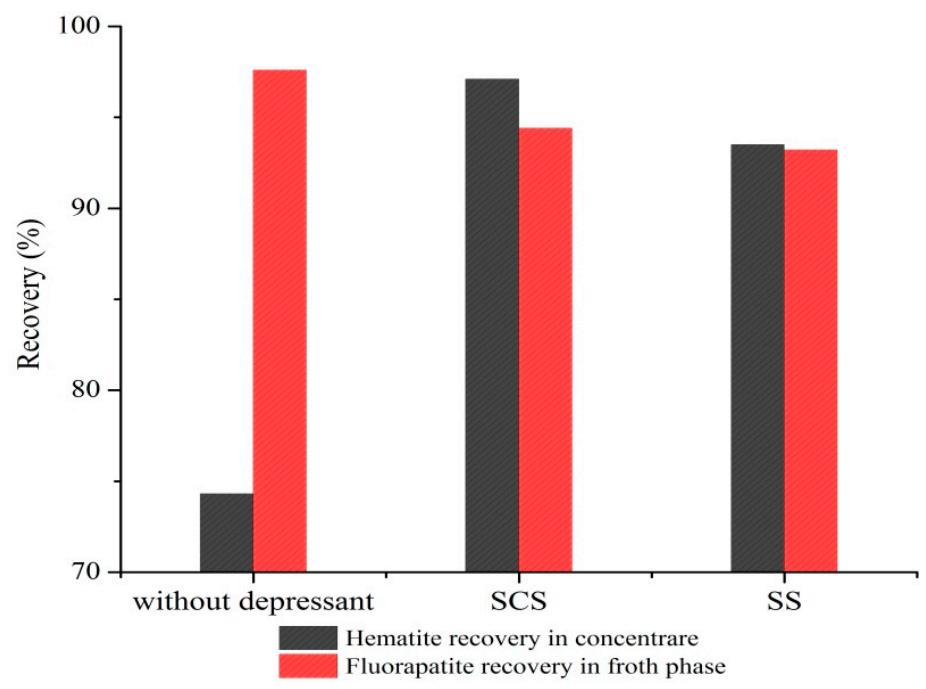

Figure 2. The results of micro-flotation tests on the pure hematite and fluorapatite by using SCS and SS at $\mathrm{pH} 9.5$.

\subsection{Batch Flotation Experiments}

In a reverse flotation of iron oxides, the depressant dosage plays an essential role and significantly can affect the iron recovery [13-15]. Exploring the effect of SCS dosage on the recovery and grade of hematite (depression) and fluorapatite (floatability) from Chadormalu samples indicates that the presence of $150 \mathrm{~g} / \mathrm{t} \mathrm{SCS}$ hematite depression is not adequate while increasing the SCS concentration to $300 \mathrm{~g} / \mathrm{t}$ can improve the iron recovery to $94.2 \%$ (Figure 3). A further increase in the SCS concentration $(>300 \mathrm{~g} / \mathrm{t})$ may increase the phosphorus content in the iron concentrate $(0.082 \%)$. It was documented that since the silicate group in SCS is dominating, a high concentration of SCS may increase the precipitation of calcium silicate on the fluorapatite surfaces. Calcium silicate precipitation can decrease the collector adsorption on the apatite surface $[12,14]$. The SCS dosage of $400 \mathrm{~g} / \mathrm{t}$ decreases the iron loss in the tails; however, it increases the phosphorus content of the concentrate (i.e., it reduces the iron 
grade) (Figure 3). $300 \mathrm{~g} / \mathrm{t}$ SCS can adjust the $\mathrm{pH}$ value of the pulp to around 9.5. Thus, in order to keep the $\mathrm{pH}$ at $\sim 9.5$ and hinder the decrease of fluorapatite floatability, a dosage of $300 \mathrm{~g} / \mathrm{t}$ SCS was selected for the industrial-scale experiments.
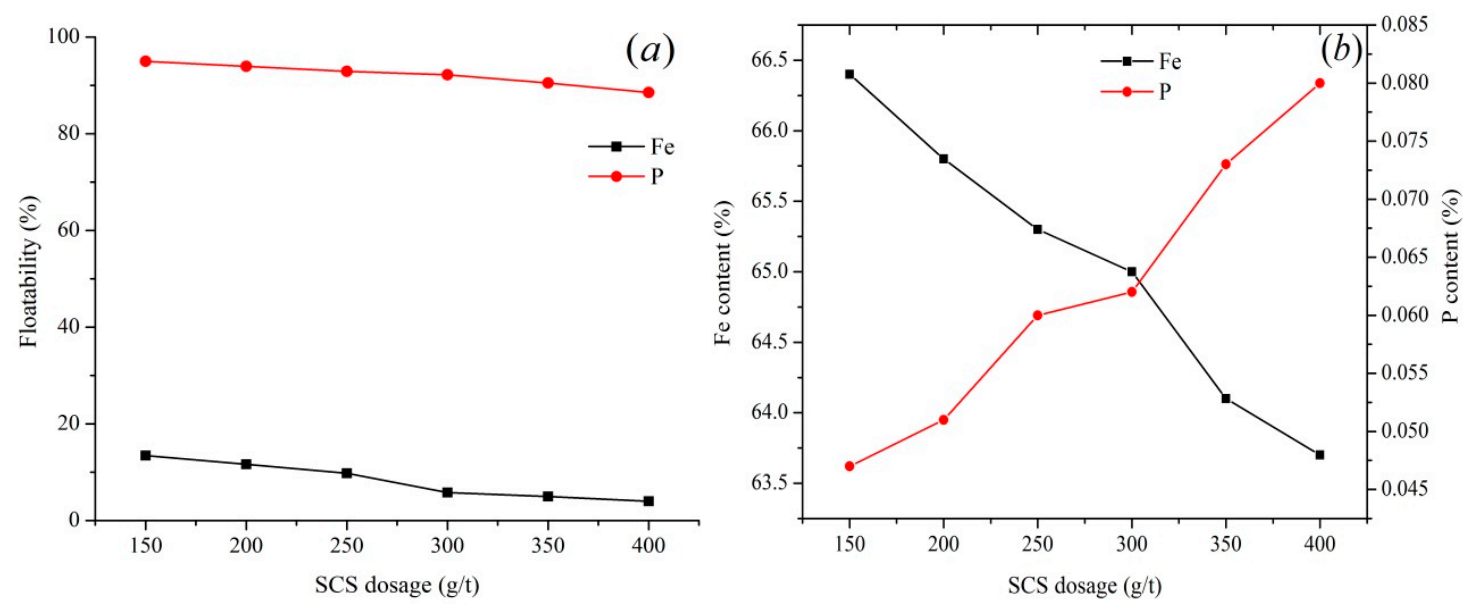

Figure 3. Effect of the SCS concentration on floatability (a) and grade (b) of Fe and P.

\subsection{Industrial Scale Experiments}

Various conditions (Table 4) are used in the three parallel circuits (lines 1, 2, and 3) in the Chadormalu iron ore processing plant. During two different days the influence of SCS vs. SS on the plant efficiency are compared. Based on the industrial experiment results (Table 5) in all the examined processing lines, when SCS is used, the metallurgical results are better than conditioning using $\mathrm{Na}_{2} \mathrm{CO}_{3}$ $+\mathrm{SS}+\mathrm{NaOH}$ (by using SCS the recovery value is increased by about $3.3 \%$ ). When conditioning by SCS, the iron content of the concentrate is increased by about $0.5 \%$ while the phosphorus content is decreased by about $0.011 \%$ in the iron concentrate compared to the $\mathrm{Na}_{2} \mathrm{CO}_{3}+\mathrm{NaOH}+\mathrm{SS}$ conditioning . Since the acceptable phosphorus content in the iron concentrate for steelmaking units should be around $0.047 \%$ [2], it can be concluded that the metallurgical results by using SCS (Table 5) are desirable for steelmaking.

Table 4. Various conditions for the industrial tests in the Chadormalu flotation circuits.

\begin{tabular}{|c|c|c|c|c|c|c|}
\hline \multirow{3}{*}{ Production Line Number } & \multicolumn{6}{|c|}{ Reagent Consumption (g/t) } \\
\hline & \multicolumn{4}{|c|}{ The First $24 \mathrm{~h}$} & \multicolumn{2}{|c|}{ The Second $24 \mathrm{~h}$} \\
\hline & SS & $\mathrm{NaOH}$ & $\mathrm{Na}_{2} \mathrm{CO}_{3}$ & $\mathrm{pH}$ & SCS & $\mathrm{pH}$ \\
\hline Production line \#1 & 400.00 & 35.00 & 160.00 & 9.67 & 290.00 & 9.36 \\
\hline Production line \#2 & 395.00 & 32.00 & 151.00 & 9.56 & 289.00 & 9.54 \\
\hline Production line \#3 & 405.00 & 34.00 & 157.00 & 9.61 & 301.00 & 9.64 \\
\hline Average & 400.00 & 33.67 & 156.00 & 9.61 & 293.33 & 9.51 \\
\hline
\end{tabular}

Table 5. Metallurgical results obtained from industrial experiments in the Chadormalu plant.

\begin{tabular}{ccccccc}
\hline \multirow{2}{*}{ Production Circuits } & \multicolumn{6}{c}{ Metallurgical Results } \\
\cline { 2 - 7 } & \multicolumn{3}{c}{ SCS (The Second 24 h) } & \multicolumn{2}{c}{ SS + NaOH + Na $\mathbf{C O}_{3}$ (The First 24 h) } \\
\cline { 2 - 7 } & Recovery\% & $\mathbf{F e} \%$ & $\mathbf{P} \%$ & Recovery\% & $\mathbf{F e} \%$ & $\mathbf{P \%}$ \\
\hline Production line\#1 & 88.25 & 65.91 & 0.055 & 85.21 & 65.08 & 0.061 \\
Production line\#2 & 90.47 & 66.14 & 0.045 & 87.48 & 65.74 & 0.06 \\
Production line\#3 & 89.68 & 66.2 & 0.044 & 85.79 & 65.91 & 0.056 \\
Average & 89.47 & 66.08 & 0.048 & 86.16 & 65.58 & 0.059 \\
\hline
\end{tabular}


Based on these results (Table 4), with a mean consumption of $293.33 \mathrm{~g} / \mathrm{t} \mathrm{SCS}$, the $\mathrm{pH}$ value can be approximately 9.51. Meanwhile, a mean $\mathrm{pH}$ of 9.61 was reported with a consumption of $400 \mathrm{~g} / \mathrm{t}$ $\mathrm{SS}, 33.67 \mathrm{~g} / \mathrm{t} \mathrm{NaOH}$, and $156 \mathrm{~g} / \mathrm{t} \mathrm{Na}_{2} \mathrm{CO}_{3}$, collectively. Therefore, the metallurgical results that are obtained from using SCS generally show superior depression performance even at the industrial scale.

\section{Conclusions}

In this study, a new synthetic depressant "sodium co-silicate" (SCS) for reverse flotation separation of hematite from fluorapatite was introduced. SCS is obtained from the synthesis of sodium metasilicate with sodium carbonate and caustic soda. SCS can provide a slurry solution in the range of $\mathrm{pH} 9$ to 10 (thus, in the presence of SCS, there is no need for a $\mathrm{pH}$ modifier). Various flotation experiments were conducted at different scales with similar conditioning: micro-flotation, and batch flotation at the laboratory- and industrial-scale. Based on the experimental results, the following conclusions can be drawn:

Results of micro-flotation tests indicated that SCS could effectively depress hematite particles whereas it did not show a significant impact on the fluorapatite flotation. Furthermore, results showed that the SCS had a higher depression impact on hematite compared to sodium silicate (SS) as the conventional depressant.

Outcomes of batch flotation experiments showed that a selective flotation separation of phosphorus from hematite for the Chadormalu iron ore samples could be achieved by using $300 \mathrm{~g} / \mathrm{t}$ SCS dosage as the depressant.

Industrial-scale test results revealed that, in the case of reverse flotation of the Chadormalu iron ore, the three different type of reagents (including: $\mathrm{NaOH}, \mathrm{Na}_{2} \mathrm{CO}_{3}$, and $\mathrm{SS}$ gel) can be replaced by just SCS while the efficiency of the plant would be increased.

Author Contributions: A.T. and R.D. conceived and designed the experiments; A.T. and O.A.R. performed the experiments; C.C.T. and J.R. analyzed the data and provided some advice; A.T. and R.D. contributed analyses and assessments; and C.C.T. and J.R. wrote the paper.

Funding: This research received no external funding.

Acknowledgments: The first and fifth authors would like to thank the management and personnel of the Chadormalu Mining and Industrial Complex and Parsulfite Chemical Company for supporting this work.

Conflicts of Interest: The authors declare no conflict of interest.

\section{References}

1. Farahat, M.; Hirajima, T.; Sasaki, K.; Doi, K. Adhesion of Escherichia coli onto quartz, hematite and corundum: Extended DLVO theory and flotation behavior. Colloids. Surf. B Bio. 2009, 74, 140-149. [CrossRef] [PubMed]

2. Tohry, A.; Dehghani, A. Effect of sodium silicate on the reverse anionic flotation of a siliceous-phosphorus iron ore. Sep. Purif. Technol. 2016, 164, 28-33. [CrossRef]

3. Nunes, A.P.L.; Pinto, C.L.L.; Valadão, G.E.S.; de Magalhães Viana, P.R. Floatability studies of wavellite and preliminary results on phosphorus removal from a Brazilian iron ore by froth flotation. Miner. Eng. 2012, 39, 206-212. [CrossRef]

4. Ma, X.; Marques, M.; Gontijo, C. Comparative studies of reverse cationic/anionic flotation of Vale iron ore. Int. J. Miner. Process. 2011, 100, 179-183. [CrossRef]

5. Iwasaki, I. Iron ore flotation, theory and practice. Min. Eng. 1983, 35, 622-631.

6. Iwasaki, I. Bridging theory and practice in iron ore flotation. In Advances in Coal and Mineral Processing Using Flotation; Chander, C., Klimpel, R.R., Eds.; SME: Littleton, CO, USA, 1989; pp. 177-190.

7. Pavlovic, S.; Brandão, P.R.G. Adsorption of starch, amylose, amylopectin and glucose monomer and their effect on the flotation of hematite and quartz. Miner. Eng. 2003, 16, 1117-1122. [CrossRef]

8. Dos Santos, I.D.; Oliveira, J.F. Utilization of humic acid as a depressant for hematite in the reverse flotation of iron ore. Miner. Eng. 2007, 20, 1003-1007. [CrossRef]

9. Chiaverini, V. Açose. Ferros Fundidos: Características Gerais, Tratamentos Térmicos, Principais Tipos, 7th edição; ABM: São Paulo, Brazil, 2008; pp. 177-178. (In Portuguese) 
10. Yu, K.P.; Yu, Y.F.; Xu, X.Y. Separation behavior and mechanism of hematite and collophane in the presence of collector RFP-138. Trans. Nonfer. Met. Soc. China 2013, 23, 501-507.

11. Tohry, A.; Dehghani, A.; Hosseini-Nasab, M. Removal of fine gangue minerals from Chadormalu iron concentrate using hydroseparator. Physicochem. Probl. Mineral Pro. 2017, 53, 259-263.

12. Potapova, E.; Yang, X.; Grahn, M.; Holmgren, A.; Forsmo, S.P.E.; Fredriksson, A.; Hedlund, J. The effect of calcium ions, sodium silicate and surfactant on charge and wettability of magnetite. Colloids Surf. A Physicochem. Eng. Asp. 2011, 386, 79-86. [CrossRef]

13. Feng, D.; Aldrich, C. Influence of operating parameters on the flotation of apatite. Miner. Eng. 2004, 17, 453-455. [CrossRef]

14. Qi, G.W.; Klauber, C.; Warren, L.J. Mechanism of action of sodium silicate in the flotation of apatite from hematite. Int. J. Miner. Process. 1993, 39, 251-273. [CrossRef]

15. Dho, H.; Iwasaki, I. Role of sodium silicate in phosphate flotation. Miner Metall. Process. 1990, 7, $215-221$. [CrossRef]

(C) 2019 by the authors. Licensee MDPI, Basel, Switzerland. This article is an open access article distributed under the terms and conditions of the Creative Commons Attribution (CC BY) license (http:/ / creativecommons.org/licenses/by/4.0/). 